Comparative Philosophy Volume 4, No. 1 (2013): 103-129

Open Access / ISSN 2151-6014

www.comparativephilosophy.org

\title{
MENCIUS' JUN-ZI, ARISTOTLE'S MEGALOPSUCHOS, \& MORAL DEMANDS TO HELP THE GLOBAL POOR
}

\author{
SEAN DRYSDALE WALSH
}

\begin{abstract}
It is commonly believed that impartial utilitarian moral theories have significant demands that we help the global poor, and that the partial virtue ethics of Mencius and Aristotle do not. This ethical partiality found in these virtue ethicists has been criticized, and some have suggested that the partialistic virtue ethics of Mencius and Aristotle are parochial (i.e., overly narrow in their scope of concern). I believe, however, that the ethics of Mencius and Aristotle are both more cosmopolitan than many presume and also are very demanding. In this paper, I argue that the ethical requirements to help the poor and starving are very demanding for the quintessentially virtuous person in Mencius and Aristotle. The ethical demands to help even the global poor are demanding for Mencius' junzi (君子chün-tzu / junzi) and Aristotle's megalopsuchos. I argue that both the jun-zi and megalopsuchos have a wide scope of concern for the suffering of poor people. I argue that the relevant virtues of the jun-zi and megalopsuchos are also achievable for many people. The moral views of Mencius and Aristotle come with strong demands for many of us to work harder to alleviate global poverty.
\end{abstract}

Keywords: Mencius, Aristotle, jun-zi (superior gentleman), megalopsuchos (magnanimous man), ren (benevolence), utilitarianism, ethics, partiality, parochial, demandingness, global poverty

\section{INTRODUCTION}

Peter Singer's article "Famine, Affluence, and Morality" is a well-known example in recent philosophy of an article that illustrates the demandingness of ethics. Ethics demands, Singer argues, that we (those of us who live in relative comfort and safety in developed countries) ought to do much more (more than most such people) to help the global poor. Singer famously argues that we are obligated to help the global, abject poor if it does not require sacrifice of something of "moral significance" (Singer's weak thesis) or something of "comparable moral importance" (Singer's

WALSH, SEAN DRYSDALE: Assistant Professor, Department of Philosophy, University of Minnesota at Duluth, USA. Email: spwalsh@d.umn.edu 
strong thesis) (Singer 1972, 231-232, 237). ${ }^{1}$ Singer argues that our obligations to help the global poor do not depend on how close the poor are to us or our family and friends. Morality demands we give significant help to the global poor, according to Singer, because morality is impartial; it does not matter that the global poor are far away and relatively unconnected to the family and friends about which we (generally) care so much.

Some have recently argued that the demands of such impartial ethics are too great. $^{2}$ It has been argued that the virtue ethics ${ }^{3}$ of the Confucian and Aristotelian traditions, by contrast, are less demanding and allow for one to be both ethical and partial to family and friends. ${ }^{4}$ It is thought that special (and partial) commitments should be part of an adequate moral theory. The early Confucian scholar Mencius, for example, says:

A gentleman is sparing with living creatures but shows no benevolence towards them; he shows benevolence towards the people but is not attached to them. He is attached to his ${ }^{5}$ parents but is merely benevolent towards the people; he is benevolent towards the people but is merely sparing with living creatures. (7a45)

In this passage, Mencius is suggesting that benevolence (仁 ren / jen) towards the people (who include the poor and the hungry) is a different kind of moral commitment than the special, partial moral attachments and commitments to one's parents (and family more generally). For Mencius, the partial moral commitment to family is especially strong and important (in part because it is the foundation for moral virtue more generally). This "partialistic interpretation" is a common interpretation of both Mencius and Aristotle (the latter focusing on the partial ethics of philia, or friendship).

\footnotetext{
${ }^{1}$ Note that, according to Singer, those ethical demands to help the poor are independent of the truth of his utilitarian moral theory. In my view, the ethical demands he argues for in his paper (to help the poor if it does not require significant sacrifice) may be either more or less demanding than utilitarianism, since it depends on what actually maximizes utility.

${ }^{2}$ For these arguments, see Stocker 1976, Wolf 1982, and Williams 1973.

${ }^{3}$ See Van Norden 2007 for an extended argument that both Mencius and Aristotle are "virtue ethicists" who emphasize the importance of human character and the morality of personal relationships (in contrast to the impartial utilitarian ethics). I will not argue here for Van Norden's thesis that Mencius and Aristotle are virtue ethicists, since I think that his arguments are sufficient (and also the "virtue ethics" moniker is not absolutely essential to my arguments in this paper).

${ }^{4}$ See Sarkissian 2010 for an overview of the recent Confucian literature that supports this view. Also see Foot's (1985) Aristotelian virtue ethical objections to demandingness.

${ }^{5}$ I would like to make a note of my use of the male pronouns in this paper. While I generally prefer to use "she" and "her" as universal pronouns, in this paper I refer to the jun-zi (as Mencius does) as a male, and the megalopsuchos (as Aristotle does) as a male. So in this paper, following Aristotle and Mencius, I use the male gendered terms (e.g., "he," "his," etc.). However, it is also important to note that the virtue of the jun-zi and the megalopsuchos can be had by anyone regardless of gender (e.g., women can be benevolent and worthy of great honors, obviously). So I take their virtue ethics to be demanding regardless of gender.
} 
However, the partiality found in these virtue ethical views has been criticized as well. Some have suggested that their partialistic virtue ethics are parochial (i.e., overly narrow in their scope of concern). For example, David Hall and Roger Ames argue that the Confucian partialistic ethic has been seen to be "provincial" and "parochial," since it is based on "graduated love and responsibility [and] intense family loyalties" (Hall and Ames 1987, 309). Hall and Ames (and other philosophers ${ }^{6}$ ) suggest that some forms of Confucian ethics seem to be overly focused on the wellbeing of family over others. ${ }^{7}$ Similarly, philosophers also have suggested that Aristotle's ethics can lead to parochialism and lack of concern for people outside of one's family and friends. ${ }^{8}$ For example, Alasdair MacIntyre says:

Aristotle's audience [in the Nicomachean Ethics]... is explicitly a small leisured minority... with a telos for one kind of life which presupposes a certain kind of hierarchical social order... All Aristotle's conceptual brilliance in the course of the argument declines at the end to an apology for this extraordinarily parochial form of human existence (MacIntyre 1966, 83). [my italics]

However, despite their partialistic virtue ethics, I believe that Aristotle and Mencius' ethics are not so parochial with respect to the concern for "outsiders"those outside the local hierarchy, the "small leisured minority," and the circle of family and friends. I believe that their virtue ethics are in many ways as ethically demanding as Peter Singer's ethics, especially regarding help for the abject poor and hungry around the world.

In this paper, I argue that our ethical commitments to the global poor and starving are indeed very demanding for both Mencius' and Aristotle's quintessentially virtuous person: the jun-zi (君子 chün-tzu / junzi) (Mencius' "superior gentleman”) and megalopsuchos (Aristotle's "magnanimous man"). The jun-zi is an ideally morally developed person, and so is the megalopsuchos. I believe that, according to Aristotle and Mencius, we (those of us who live in relative comfort and safety) should strive toward this moral ideal if we can indeed make substantial progress towards it, and that it is possible for a wide range of people to make substantial progress toward the ideal.

Moreover, the differences between Mencius' jun-zi and Aristotle's megalopsuchos are not as great as many believe. Both Mencius' jun-zi and Aristotle's

\footnotetext{
${ }^{6}$ See Sarkissian 2010 for an overview of the literature on Confucian views on partiality, and how this partiality is interpreted as unfair favoritism. Qiyong (2007) and Qingping (2007) also discuss the charge of familial partiality and nepotism in Confucianism at length.

${ }^{7}$ Hall and Ames do not believe this narrow parochialism or provincialism is ultimately a problem for the ethics of Confucius or Mencius themselves. However, Hall and Ames do believe that a narrow parochialism did become a part of some forms of what came to be understood as Confucianism in the Chinese Empire. Imperial and institutionalized Confucianism, according to Hall and Ames, has suffered from provincialism and parochialism, but has done so by straying from the ethics of Confucius and Mencius. I would like to thank my reviewers for encouraging me to make this important point clear.

${ }^{8}$ See Jeske 1997 for an overview of the Aristotelian view of partiality.
} 
megalopsuchos have the virtues to the highest degree. However, ethics may seem (on the surface) more demanding in a number of ways for the jun-zi but (according to some interpreters) not the megalopsuchos. The jun-zi may seem (to some) to have a wider scope of concern for the common people, a special concern with hunger, and a wider scope of locations and places with which he is concerned. The virtues of a jun$z i$ may seem (to some) more achievable for normal people, and the jun-zi seems to be more accessible to the common people. Thus, on some interpretations, the jun-zi (unlike the megalopsuchos) is concerned with more people in more places; more people could become a jun-zi, and the jun-zi seems less aloof than the megalopsuchos. ${ }^{9}$

However, the megalopsuchos' ethical life, like the jun-zi's, is very demanding, and includes similar demands to help the poor and hungry. The scope of these demands for the megalopsuchos may well extend across the traditional polis (the city) and beyond (as it does for the jun-zi). The megalopsuchos could very well be strongly motivated to alleviate global poverty. I end the paper by suggesting that these significant demands to help the global poor are not inconsistent with the Aristotelian and Mencian partial moral commitments to family and friends. I suggest that the moral demands of the jun-zi and megalopsuchos may be, on balance, as or more demanding that the demands Singer makes of us in "Famine, Affluence, and Morality".

\section{CONCERN FOR THE POOR \& HUNGRY}

Mencius' jun-zi is a person who maintains his original heart, is supremely benevolent and empathetic, and loves and respects others (4b28, 6a6, Cf. 7a37). Mencius often notes that the $j u n-z i$ is concerned with the people's famine and starvation. One of the greatest enjoyments for a jun-zi is to share goods with the common people (1b1-4). The jun-zi values true achievement and true reputation, and first tries to benefit others (6b6). Mencius says, "All that is required of a jun-zi is benevolence (ren)" (6b6). The jun-zi follows the golden rule by treating others as he wishes to be treated, and the best way to follow this rule is through benevolence (ren) (7a4).

Mencius says that the common people and their hunger are the supreme concern of both the jun-zi (7b14) and the true king (1a3, 1a7). For Mencius, a true king is a kind of $j u n-z i$ and is said to be alike in goodness to a jun-zi (7a8). For Mencius, the jun-zi, including the true king, must work to establish the wellbeing of the poorest people. For example, a normal person who is a jun-zi supports and works to achieve the goals of a true king, who is especially focused on issues of famine (5a1, 7b32). According to Mencius, the jun-zi (who happens not to be a king) taxes the people in a way that prevents hunger and famine (7b27). Of the true king, Mencius says that he cares for the common people as if they were his own children (1a4) and his own feet and hands (4b1). Mencius says that a king who has food on his plate but has starving

\footnotetext{
${ }^{9}$ Sherman (1988) and Hardie (1978) suggest that Aristotle's megalopsuchos is not particularly interested in helping a wide range of people.
} 
citizens is like a murderer (1a3-4, 3b9). The true king takes the suffering of even one common person as a personal affront (1b4). The true king (who is a kind of jun-zi) also gives first consideration for those who are the most destitute (1b4). ${ }^{10}$ So Mencius' jun-zi is very concerned with the plight of the poor and starving, and the true king (as a kind of $j u n-z i$ ) is in a special position to help the poor and starving.

In contrast to Mencius' account of a jun-zi, Aristotle never outright says that a megalopsuchos is especially concerned with the good of the common people or starving people in particular. The megalopsuchos is defined by Aristotle in terms of the megalopsuchos' rightly deserving great honors (1123b1-1124a20). The megalopsuchos has done great things, knows it, has received great honors for it, and deals with the honors appropriately. Themistocles, who arguably saved Greece from King Xerxes' Persian invasion in $480 \mathrm{BCE}$, is a kind of (failed) candidate for megalopsuchia (magnanimity). ${ }^{11}$ Themistocles (a) has the right scope of concern (the Athenian polis and the survival of Greek society and culture more generally), (b) does things that deserve great honor, and (c) knows he deserves great honors. Despite having these features of a megalopsuchos, Themistocles fails to be megalopsuchia because he does not deal with honors appropriately; he is obnoxious and brags to the common people — which Aristotle specifically says is not magnanimous (1124b5-9). Because of his bragging (and thus his not dealing with honors appropriately), Themistocles fails to be megalopsuchia and is ostracized and exiled from Athens.

However, some interpreters have thought that Aristotle's megalopsuchos is not concerned with the poor and starving. For example, Aristotle says that the megalopsuchos is a "sluggish" man of "few deeds" who seems oftentimes (according to some interpreters) to be at leisure (1124b23-26), even though starvation and famine were probably common in Aristotle's day. If starvation was prevalent, why is the megalopsuchos at leisure? The answer (which I will discuss in more detail later) is that Aristotle is not saying that the megalopsuchos is at leisure; Aristotle is only saying that it is fine for a great man to be at leisure when there is nothing great to do (and their often is something great to do). Mencius' jun-zi, as I have argued, is supposed to have constant concern for the hungry, and identifies his success in terms of how much he can help the poor and hungry. However, some have interpreted that because the megalopsuchos is "unassuming toward the common people" (1124b1723), he will not care for the people. According to such interpreters ${ }^{12}$, Aristotle's megalopsuchos is primarily concerned with honor rather than poverty (1123b21-22, 1124a4-5).

However, I believe that Aristotle's megalopsuchos is much more like the jun-zi in his concern for others than some might think. For example, the jun-zi, like the

\footnotetext{
${ }^{10}$ For a discussion of Mencius on benevolent (ren) government and the role of the true king, see Curzer 2012.

${ }^{11}$ According to Plutarch's Lives, Themistocles was largely responsible for saving Greece from the Persian invasion. In Book I of the Peloponnesian War, Thucydides said that Themistocles was one of the greatest geniuses of his day.

${ }^{12}$ Sherman $(1988,103)$ and Hardie $(1978,69-74)$ suggest that Aristotle's megalopsuchos is often at leisure and does not care for the common people.
} 
megalopsuchos, is somewhat aloof from (in that he is not overly familiar with) the common people; after all, a jun-zi shows benevolence (ren) toward the common people, but is not specially attached to them as he is to his parents (7a45). Moreover, when Aristotle says that the megalopsuchos is "unassuming" toward the common people, Aristotle means that the megalopsuchos (unlike Themistocles) does not brag about his deeds to the common people; Aristotle does not mean the megalopsuchos does not help the common people (I will soon argue that the megalopsuchos is indeed concerned with the wellbeing of such people). It is unvirtuous, Aristotle says, for a megalopsuchos to act "lofty" around the people, since it is "as vulgar as a display of strength against the weak" (1124b18-23). Thus, the megalopsuchos (unlike Themistocles but like the jun-zi) is modest and unassuming around the people. ${ }^{13}$

Importantly, Aristotle argues that the megalopsuchos cares a great deal about the wellbeing of others. Aristotle says the megalopsuchos is apt to confer benefits on others and is apt "to ask for nothing or scarcely anything, but to give help readily" (1124b9-19). Moreover, it is important to remember that the megalopsuchos' help given to others is great help, and this help is worthy of great honor. For example, the benevolence of the megalopsuchos sounds a lot like that of the famed Paul Farmer, who works as a physician to the poor in Haiti. ${ }^{14}$ Farmer does great things for the poor, and deserves great honors as a result. It is Farmer's benevolence that makes him worthy of great honors. Benevolence is one of the marks of honor-worthiness. Aristotle says that "since the megalopsuchos deserves the most [honor], he must be good to the highest degree" (1123b26-7). The goodness to the highest degree to which Aristotle refers is goodness (and benevolence) toward those in the polis (I will discuss more about this benevolence to the polis later). According to Aristotle, the megalopsuchos is also willing to face the greatest dangers and even sacrifice his life and die for the good of others (1124b8-9). This shows that the megalopsuchos is beneficent, since he works effectively for the good of others, and is willing even to die for the good of others. While Aristotle does not discuss a virtue of benevolence per se, great benevolence is an essential feature of Aristotle's virtue of megalopsuchia, which he calls the crown of the virtues.

So, a key feature of a megalopsuchos is the exercise of his great beneficence that is worthy of great honor (so great that he is willing to die for the wellbeing of others). This beneficence sounds like that in Mencius' discussion of the jun-zi's exercise of ren that saves the poor from starvation. Moreover, Mencius' jun-zi is also willing to die in pursuit of benevolence towards others (3b1, 5b7, 6a10, Cf. Analects 15.9). Great beneficence toward others, even if it requires sacrificing one's own life, is a key commitment in both the megalopsuchos and the jun-zi. And note that Mencius is not entirely unconcerned with honors either, as when Mencius says "Benevolence brings honor, cruelty disgrace" (2a4). Mencius specifically says that the jun-zi deserves honor because of his great benevolence (2a4, 6a16). Similarly, as I argued above, Aristotle says that the megalopsuchos also deserves honor because of his great

\footnotetext{
${ }^{13}$ See Curzer 1991, 133 for a discussion of the modesty of the megalopsuchos around common people.

${ }^{14}$ For a discussion of Paul Farmer's magnanimity, see Kidder 2003.
} 
beneficence. So both the jun-zi and megalopsuchos deserve honor for helping others in great ways.

For the megalopsuchos to deserve great honor, he must do great things for the benefit of the polis. In the Nicomachean Ethics, Aristotle says that to achieve the good of the polis is the greatness end of the virtuous agent (1094b8-12). I believe that the benevolent megalopsuchos is apt to address famine and similar emergencies within the polis (I will argue later that today this "polis" might extend in scope to that of modern-day global poverty). If there is starvation and famine among the people of the polis and the megalopsuchos does not address it, the only legitimate reason can be that there is another great (or greater) benevolent thing to do for the community. However, famines and starvation are significant community emergencies. If there is not another great thing to do for the polis and a person does not respond to starvation, then that person really is not a megalopsuchos. After all, the megalopsuchos must respond to such an emergency in the polis (unless there is another great action that is also of fundamental importance to the polis or there is another megalopsuchos sufficiently on the job). Beneficence and great actions worthy of honor are required of those with megalopsuchia (magnanimity). Since there are plenty of opportunities to address famine, and famine is under-addressed today, the megalopsuchos would likely work to address famine that is widespread in the polis (and I will argue that famine is indeed widespread in our polis today).

So, if there is a great thing to do, the megalopsuchos must do it or another great thing. I believe that, for the megalopsuchos, starvation and famine undermines the wellbeing of a polis to such an extreme extent that this kind of emergency often would get priority over other great acts. However, if there is another option that would also be great for the polis, then the other option must be very beneficent and beneficial to the community; the megalopsuchos must still be truly worthy of great honor despite having chosen not to address the starvation and famine. However, I suspect that this will often not be the case, given the dangers to the community associated with famine, and given the benevolence of the megalopsuchos. Nevertheless, saving a significant proportion of people in the polis from starvation and famine (a) is a response to a serious emergency in the polis, (b) is a great thing to do, (c) is benevolent, and (d) is worthy of great honor. This is just the kind of thing the megalopsuchos does. After all, as I just argued, the megalopsuchos is described by Aristotle as someone who is so beneficent that the megalopsuchos is willing to sacrifice his life in order to help others. The megalopsuchos is particularly concerned with the wellbeing of the polis itself, and famine and hunger is obviously a serious problem for the polis if the polis is the whole world (as I argue later).

\section{MANY CAN HAVE THE DEMANDING VIRTUE}

Mencius says that any one of us can become a jun-zi, and then says that anyone can do this by becoming like the sage Emperor Shun by retaining and cultivating one's original heart and mind (by cultivating the four sprouts) $(4 \mathrm{~b} 28,6 \mathrm{~b} 2)$. In the famous "sparing the ox" example, Mencius says that any king can be a true king (a kind of 
jun-zi), since all people have capacities for empathy and the capacities to extend empathy (1a7, Cf. 2a6). Mencius says this empathy is most realized in making sure the common people have sufficient food and a good life (1a7). Mencius says most anyone can and ought to become a jun-zi since one becomes a jun-zi simply by developing the virtues through extending one's innate sprouts that all humans have (2a6).

When addressing the question of whether just any "ordinary man" can become a jun-zi, Mencius says that "One should become like [the fully virtuous sage] Shun. That is all." (4b28). Mencius also says that "anyone who exerts oneself will also become [fully virtuous] as Shun was" (3a1). All that is required to become a jun-zi, Mencius says, is "to make an effort" (6b2). So on Mencius' view, not only can any person become a jun-zi, but also any person should become a jun-zi. Mencius' view that we all ought to work toward the level of virtue of the jun-zi is shared by Stephen Angle when he says that "We (Confucians) are committed to seeking full virtue" (Angle 2012, 29). We can and should work towards full virtue. If Mencius is right, most any person can become a jun-zi, albeit after years of hard work. ${ }^{15}$ Mencius suggests that it is as crazy to stop short of developing full virtue as it is crazy to dig a well and stop short of water (7a29).

In contrast, Aristotle may seem (at first glance) to say that only the very few can have the level of virtue found in the megalopsuchos (1126b26-1124a4). Magnanimity implies one who is worthy of great honors and deals with the honors appropriately, and also implies one has all the virtues to the highest degree (1123b26-30, 1124a1-4). However, I believe that for Aristotle becoming a megalopsuchos is not as impossible as some might think. Aristotle does say that in fact there are very few megalopsuchoi (much as Mencius says few are a jun-zi), but that does not mean that few could become one.

First, some have said that few can become a megalopsuchos because a megalopsuchos must be wealthy. However, Aristotle says that the megalopsuchos is self-sufficient and does not need wealth or many external goods to support his greatness (1125a11-12, 25-26). ${ }^{16}$ In the Posterior Analytics Aristotle says that (the impoverished) Socrates is a model for the megalopsuchos (97b15-25). Moreover, Aristotle says that the megalopsuchos is a person of great virtue regardless of wealth (1124a20-1124b6), and that the megalopsuchos even remains noble in the face of poverty and misfortune (1100b22ff). Aristotle also says that the megalopsuchos is unconcerned with wealth (and "will take a moderate view of wealth"), lives surrounded by only a few simple, inexpensive material things (as "his possessions are noble but unprofitable"), and is self-sufficient without need of wealth (1124a201124b6, 1125a1-12).

\footnotetext{
${ }^{15}$ Becoming a jun-zi or megalopsuchos, I think, is a little like mastering calculus. I have had many students claim that they cannot possibly master calculus. However, each step in the mastery of calculus is well within their power, and if they practice step-by-step with practice-problems every day, in a year's time most any of my students would master Calculus I and II.

${ }^{16}$ For a discussion of the megalopsuchos' poverty, see Curzer 1991, 135.
} 
Moreover, the jun-zi is not necessarily wealthy as well. One does not need to be wealthy or powerful to help others the way that either the jun-zi or megalopsuchos do. Mencius says that the jun-zi "cannot be bought" (2b3) and has a "consistent heart and mind" even "without constant material means" (1a7, 3a3). One does not need to be rich and powerful to be a jun-zi or megalopsuchos. Modest means are all that is required. ${ }^{17}$ Mencius says that "The Way is like a wide road. It is not difficult to find. The trouble with people is that they do not look for it" (6b2).

I believe that Aristotle holds a similar view, and that while both Mencius and Aristotle believe that few are a jun-zi or megalopsuchos, many could be one if they sought to do the relevant actions, and there are indeed many opportunities for many people to do the relevant actions. For example, Howard Curzer notes that the megalopsuchos will find ample opportunities for great action if he seeks them out; the megalopsuchos is only sluggish and leisurely if there is nothing great to do (but that is one big "if," since there are usually great things to be done). Curzer notes,

...opportunities for spectacular actions [for the megalopsuchos]...are not rare.... [A]s Arthur Conan Doyle says, "Chances are all around you. It is the mark of the kind of man I mean that he makes his own chances. You can't hold him back... There are heroisms all round us waiting to be done." (Curzer 1991, 139)

Leisure is only possible for the megalopsuchos when there is nothing to do that is worthy of great honor; but tackling famine and starvation problems is magnanimous and worthy of great honor, and is often an available option. Even if there may have been occasionally no such opportunities for magnanimous action and thus leisure opportunities for the magnanimous man in Aristotle's day, this is not the case today. Many people today have ample opportunities to do magnanimous actions if only they would look around for the opportunities. Advantaged people from developed counties have many opportunities to practice and develop magnanimity. The jun-zi and megalopsuchos are in situations in which they can help those in need, but this is a common situation that many people are in. Many people are in positions in which they can give significant help to others. ${ }^{18}$

So the opportunities to practice magnanimous actions are common and plentiful for many people. Importantly, if there are plentiful opportunities to practice virtue, then there are plentiful opportunities to develop virtue, since Aristotle suggests we become virtuous (e.g., courageous) by practicing doing virtuous actions (e.g., courageous actions) (1103a1ff). Aristotle suggests that over time and through practice and habituation, many people can become courageous if there are plentiful opportunities to practice. Similarly, most people could also slowly become magnanimous by practicing doing magnanimous actions (maybe starting with actions

\footnotetext{
${ }^{17}$ Walsh (forthcoming) discusses at length the modest means needed by the jun-zi and megalopsuchos to develop full virtue.

${ }^{18}$ For example, Bruno Serato, a small restaurant owner in Anaheim California, decided to feed hungry children pasta daily at the Boy's and Girl's Club. Bruno Serato feeds a large number of children daily for $\$ 2000$ per month. Serato is listed as a "CNN Hero".
} 
worthy of small honors, and moving up from there to actions worthy of greater honors). It might take most of a lifetime of practice to get to the full virtue, and it certainly would require much effort and work, but many people have the time and opportunity to give such effort and practice such virtue. It is not that few can become magnanimous; it is merely that few go through the tough and tedious years of practice.

Moreover, on Aristotle's view, if we can become megalopsuchia, we should try to become megalopsuchia. If we can become a megalopsuchos, we ought to, for the same reason that we ought to be virtuous if we can be virtuous. Aristotle does not say that those who have the opportunity be virtuous can (ethically) opt out of being virtuous. For Aristotle, to be virtuous means one has hit the mean, and to fail to be virtuous means one has missed the mean. For Aristotle, to miss the mean is to engage in a kind of vice, and it is never morally acceptable to engage in vice when one had the opportunity to be virtuous. If one can hit the mean, one ought to hit the mean. So given that one can become magnanimous (or at least work towards it) by practicing the right kinds of actions (as practice is the road to virtue according to Aristotle), one ought to become magnanimous as well. ${ }^{19}$

Some might object at this point and say that the life of a jun-zi or megalopsuchos is too demanding. This objection, however, is a red herring. For Aristotle and Mencius, people have such intuitions that the life of a jun-zi or megalopsuchos is too demanding because they are inferior minded. Mencius says, "The doings of a jun-zi are naturally above the understanding of the ordinary man" (6a6). Aristotle, I believe, says that for the non-virtuous to hit the mean, one often must aim beyond what one thinks is the mean because a common moral intuition is to think the mean is easier than it really is. Aristotle suggests we often should avoid the easier extreme, since we often have a natural vice to think that what we ought to do is on the easy side of the mean (1109a30-1109b25). For example, Aristotle suggests that the more typical, natural vice is to be too apt to indulge in pleasure (rather than being insensitive and immune to pleasures) (1119a1-20), and that humans are generally much more naturally apt to be too stingy than too giving (1121b15). Similarly, Aristotle might say that we are more naturally apt to make things easy for ourselves in our ethical commitments. For Mencius and Aristotle, many are apt to be (ethically) undemanding of themselves, and should overcome their intuitions that try to justify being undemanding. ${ }^{20}$

\footnotetext{
${ }^{19}$ One might argue that the world only needs a few people to be jun-zi or megalopsuchos. First, even if this is true, the world is still woefully bereft of such people, and is likely to always remain so. Second, a Jun-zi or megalopsuchos can come from all walks of life, and thus anyone in most any set of circumstances can be fully virtuous. So it is not as if an overabundance of virtuous people will lead to an underabundance in other important areas of life.

${ }^{20} \mathrm{Cf}$. 6a8, in which Mencius tells the story of Niu Mountain. Niu Mountain is only barren because it is trampled and the natural sprouts cannot grow. The trampled state is analogous to a human being who has not let her natural moral sprouts grow into full virtues. If a human is in such a "trampled state," one's moral intuitions will likely be deficient and unreliable.
} 


\section{THE GLOBAL SCOPE OF THE JUN-ZI AND MEGALOPSUCHOS}

However, would the jun-zi and megalopsuchos help the global poor and those experiencing famine in distant, far off places? I argued earlier in the paper that the $j u n-z i$ is especially concerned with the poor and famine in particular, but I did not discuss famine in distant places. However, Mencius suggests that the jun-zi is not particularly limited in how far away he extends his benevolence to those who are starving. Mencius says, "Loving one's parents is benevolence (ren)... What is left to be done [to become a jun-zi] is the extension of [this] to the whole empire" (7a15) [my italics]. Mencius repeatedly says that the jun-zi's concern extends to the "entire empire" (1b1, 1b3-4) and "all within the Four Seas" (1a7). The jun-zi delights in "bringing peace" to "the whole empire and all within the Four Seas" (7a19, 7a21). The jun-zi is ren towards people generally, as an extension of the ren he has for his own family (7a45). Also, the best jun-zi makes friends with people from other villages, other states, and throughout the empire (5b8).

So the scope of benevolence (the scope of ren) is very wide for a jun-zi. I should note that the word being translated as "empire" is tian-xia (天下), which more literally means "all under heaven". Tian-xia, in contemporary interpretations of both Classical Chinese and Mencius, is also often translated "the whole world". ${ }^{21}$ Admittedly, Mencius does not make it absolutely clear in these passages whether he means tian-xia in a more limited sense of "the empire" or in the more expansive sense of "the whole world". However, it is clear that the scope of benevolence for the jun-zi is very wide indeed. It is clear, for example, that the jun-zi cares for people from other states and villages. So for Mencius the jun-zi's ren (benevolence) is extended far and wide, and the jun-zi is committed to the good of a wide range of people that he can help (so long as that does not contradict his filial duties; I will discuss this more later). So a concern for the suffering of the global poor is something a jun-zi would be apt to have (especially on the "whole world" interpretation of tian-xia). If the scope of tian-xia is limited to a smaller sense of "the empire," then the jun-zi's benevolence (ren) towards the poor of the empire is still significant in scope.

However, Aristotle's megalopsuchos might seem to be comparatively limited in his benevolent concern, and limit his concern to his own polis. Themistocles, for instance, focuses on saving the Greeks (his own people) from the Persian invasion. However, there are a few reasons to think that the scope of the contemporary magnanimous man's concern would be extended farther than the city limits typical of a traditional polis. I will argue that the contemporary magnanimous man's concern may very well be for the whole world, and thus include the global poor.

First, in Aristotle's day, it may not have been possible for a typical megalopsuchos to have a wider scope of effective, significant benevolence beyond the boundaries of a small, traditional polis. In ancient Greece, it would have been

\footnotetext{
${ }^{21}$ See Mingming 2012 for an account of tian-xia as generally meaning "the whole world on earth under heaven" in Classical Chinese. $\operatorname{Kim}(2011,380)$ suggests a translation of "the whole world" for tian-xia in Mencius. I would like to thank a reviewer for pointing out the subtleties of tian-xia.
} 
much more difficult to have an effective scope of action far beyond the small, traditional polis. ${ }^{22}$ However, Aristotle clearly wants the megalopsuchos to have a great, wide scope of action. The wider the scope of action, the more worthy of great honors he is. Aristotle might be happy that today a wider scope of action is an option for the megalopsuchos. It is now within the abilities of many people to effectively exercise action over a wide range of places around the globe. In the Nicomachean Ethics, Aristotle suggests that to have a wide scope of action, like a kind of god, is a mark of the greatness of the activity which is worthy of great honors, and that this scope is that of the polis. ${ }^{23}$ Aristotle says:

...it is finer and more godlike to attain the good for a nation or for city-states $\left(\right.$ polesin $^{24}$ ). These, then, are the ends at which our inquiry aims, since it is political science, in one sense of that term. (1094b8-12) [my italics]

So when Aristotle says that the proper scope of action for the most virtuous person is indeed the whole polis, he means that the greater, more godlike scope of action is best. If a wider scope of action is truly available today (since we are better able to affect a wider range of people today), then the megalopsuchos would choose that wider scope of action (i.e., a more global scope). Also note that when Aristotle says "to attain the good for a nation or for city-states" (1094b8-9), he is referring to a kind of benevolence that the megalopsuchos would willingly die to achieve (1124b89).

Moreover, the same argument could be used even if one interpreted Mencius to be using 'tian-xia' to mean the more limited sense of "the whole empire" rather than "the whole world". In other words, even if Mencius was using 'tian-xia' in the limited sense of "the empire of his day" (as Aristotle may have used 'polis' to mean "the citystate of his day"), Mencius may have been using the term to indicate something like "the largest effective scope of action for a jun-zi". If that is the case, it is arguable that the whole world would be tian-xia today, since the jun-zi's scope would be larger today than it was in Mencius' day.

Second, today the polis itself may be the entire world, and the polis may no longer be limited to a small city. Consider Aristotle's definition in the Politics of the polis as an economically self-sufficient community (1252b33-34, 1253a1-20). ${ }^{25}$ Today, with

\footnotetext{
${ }^{22}$ In the Politics, Aristotle does suggest that the best polis has only a limited number of people since the best polis is merit-based, and people should know each other well to be able to give civic duties based on merit (1326a1-1326b25). The global world, then, might be too large for being the best polis, since it is difficult to know so many people. However, Aristotle does not limit the megalopsuchos to great actions in only the best polis. Indeed, one of the things that makes the megalopsuchos great is that the megalopsuchos helps an imperfect polis become better.

${ }^{23}$ Aristotle often says that it is best to be as godlike in one's actions and activities as possible, and this included the scope of one's actions being godlike and great. Aristotle says, "the best thing in the universe is [a god and] not a human being" (1141a21-23).

24 "Polesin" is the dative plural form of the Greek term polis, which is the nominative singular form.

${ }^{25}$ Meikle (1995, 44-45) and Mayhew (1997, 37-58) argue that, on Aristotle's view, mere economic self-sufficiency is necessary and sufficient for a community's being a polis. I am not necessarily
} 
economic globalization (and the related international legal institutions and norms) the whole world may be a polis, with its somewhat unified legal and economic structures. While it is true that the global institutions are not perfectly integrated economically, legally, or normatively, neither was Aristotle's polis of Athens. Today's global norms, laws, and economies are fragmented, but every community is fragmented. So the whole globalized world, economically interconnected now more than ever, may be the polis qua "economically self-sufficient community". If the global world today is indeed interdependent economically in the relevant ways, then the scope of the megalopsuchos' beneficent actions is that of the entire world (i.e., the contemporary polis of today). So the megalopsuchos' commitment to the wellbeing of the polis might now be a commitment to the wellbeing of the world, and that would include the global poor. As I argued earlier, extreme famines are a particularly important kind of emergency in a polis, and the wellbeing of the polis is of particular concern for the megalopsuchos.

Third, even if one is limited to great benevolent actions within a traditional polis, one can still do a lot of good work for others (including the poor and hungry). Ethics within any polis is still very demanding for the megalopsuchos. The megalopsuchos will do great things for others and ask little in return, as Aristotle says. There is great poverty and hunger in most any polis, and this gives the megalopsuchos opportunities to exercise his great beneficence, in which he is prepared to sacrifice his life for the good of others.

\section{MENCIUS ON PARTIALITY AND THE DEMANDS OF BENEVOLENCE}

However, for Mencius and Aristotle, how does the partiality of ethics dovetail with the ethical demands to help so many poor people? I will end this paper by taking up this question. Recall that Mencius repeatedly says that the jun-zi's concern extends to the "entire empire" (1b1, 1b3-4) and "all within the Four Seas" (1a7). The jun-zi delights in "bringing peace" to "the whole empire and all within the Four Seas" (7a19, 7a21). Also, the best jun-zi makes friends with people from other villages, other states, and throughout the empire (5b8).

Consider what Mencius says at length:

There are no young children who do not naturally love their parents, and when they grow up will not respect their elder brothers. Loving one's parents is benevolence (ren); respecting one's elders is righteousness ( $y i$ 義). What is left to be done is simply the extension of these to the whole empire. (7a15) [my italics]

What Mencius is saying, I believe, is that being ren toward the whole empire is not only consistent with filial piety (xiao 孝) for and attachment to one's parents (7a45), but also is a naturally good and necessary outgrowth of it. Mencius' jun-zi

committed to such a narrow economic view of the definition of a polis, but my arguments here are consistent with their view. 
extends love for family as far as he can to others, while remaining xiao toward the family. For Mencius, the filial foundation of the partial ethical commitment to family ought to lead to an ethical commitment to the poor throughout the empire. Mencius' $j u n-z i$ extends the ren for the family as far as he can to ren for others (while remaining ren and xiao toward the family). My interpretation of 7a15 is made more plausible by what Mencius says at 1a7:

Treat your elders as elders, and extend it to the elders of others; treat your young ones as young ones, and extend it to the young ones of others; then you can turn the whole world in the palm of your hand. The Odes say,

He set an example for his wife,

It extended to his brothers,

And so he controlled his family and state.

This means that he simply took this heart here and applied it to there. Hence, if one extends one's ren, it will be sufficient to care for all within the Four Seas. If one does not extend one's ren, one will lack the wherewithal to care for one's wife and children. That in which the ancients greatly exceeded others was no other than this. They were simply good at extending what they did. (1a7). [my italics]

The key to being a jun-zi is extending one's ren toward one's parents and one's $y i$ toward one's elder brothers to (essentially) the whole world (what Mencius calls "the whole empire" and "all within the Four Seas") (cf. 7b31). However, it is important to note that if one does not extend the ren to others, one fails to be ren to one's family.

A key line in $1 \mathrm{a} 7$ is "If one does not extend one's ren, one will lack the wherewithal to care for one's wife and children." I believe this line indicates a number of things. One is that being ren pervades one's character if one understands and is committed to the value of ren in the familial relationships. If it pervades one's character, one has the ren relationship with non-family-members as well. Moreover, for Mencius, having a virtuous and benevolent son or daughter that has extended his or her ren is good for the parent. So, for example, to be ren to others is also to be xiao to one's parents. The partial virtues are supposed to become more global virtues that express ethical concern for all. This suggests a unity and a harmony among the virtues as expressed both in the family and for all in the world. But Mencius is clear that if one does not extend ren beyond the family, one fails to have ren for one's own family.

Note that Mencius also says that ren is a fundamental good of human relationships sans phrase. Ren is the foundation of the good relationship that the jun$z i$ has for people generally. Mencius says,

A jun-zi is sparing/compassionate with living creatures but shows no benevolence (ren) towards them; he shows ren towards the people but is not attached to them. He is attached to his parents but is merely ren towards the people; he is ren towards the people but is merely sparing with living creatures. (7a45)

The morally mature person is ren toward all people in the empire and all people within the Four Seas. While Mencius says that a jun-zi does have a special "attached" 
relationship with the jun-zi's own family (in addition to having ren towards one's family), a jun-zi must have ren, a strong form of benevolence and love, towards people generally. Ren is the foundation for all full, good human relationships.

However, this brings up the idea that there may be a conflict between the (a) commitments that come with "merely ren" people-relationships vs. (b) commitments that come with "ren+attached" family-relationships. I think there is indeed a sort of general conflict between helping family and others, but the conflict is much like the conflict the virtuous has throughout a virtuous life. The virtuous may have a sort of conflict between commitments to, say, two different members of the virtuous' own family, since one can only do so much for one member of the family before sacrificing time and effort for other members of the family. I will explain this kind of conflict with an example.

Consider the example of conflict for someone who is both a virtuous teacher and a virtuous parent. As a virtuous teacher, she will do much for her students; as a virtuous parent, she will do much for her children. For such a virtuous person, the demands of virtue are very, very substantial for both the good of the students and the good of the family. She will work very hard for the good of both groups.

So there is no conflict for such an agent, typically, between the general demand to work hard for the family and the general demand to work hard for the students. Hard work and much good can be done for both groups by one and the same person in a single lifetime. There are many ways for a virtuous agent to fulfill the demands for both family and students.

However, there is the conflict between how much time and effort to spend on one rather than the other. The virtuous agent will not spend so much time and effort on the students that she ignores her family or vice versa. Even the virtuous agent is limited in what she can do in a lifetime, and she will need to be limited in what she does for either group. This limitation does not force virtuous agents to be ren (substantially benevolent) to one group but not another.

However, in some ways and at some times, the teacher's efforts will be like a zero sum game; time spent on one group will sometimes take away from time spent on the other. Such conflicts arise due to the limits of human abilities and powers. Finite creatures like us can only do so much in a day or a lifetime. Aristotle's golden mean is meant, in part, to adjudicate how such a virtuous person balances duties to family and duties to students (both types of duties remaining substantial). Similarly, Aristotle's golden mean can adjudicate how a virtuous person balances duties to family and duties to the global poor (both duties remaining substantial).

However, in other ways it is not like a zero sum game; part of being a good family member is contributing to the good of the polis and extending one's virtues in the community. In part, this is what Mencius meant when he said that the good of Shun's family was in Shun's extending himself into the community by having children (despite their objections that Shun should never marry at all). Mencius says: 
There are three forms of unfiliality, and bearing no heirs is the worst. Shun married without telling his parents because he was afraid of leaving no heir. The jun-zi understands this as equivalent to telling his parents. (4a26)

Mencius is suggesting that extending oneself into the world (through marriage and children) is itself a filial duty. In 5a2, Mencius says that Shun did not tell his parents that he was to be married because his parents would have prevented him from having a wonderful marriage, and Mencius suggests that Shun's having a wonderful marriage is good for Shun's parents. As it is good for a parent to have a good son, it is good for a parent to have a good teacher for a child (or most any sort of good child, for that matter). I argue later that it is good for the megalopsuchos' friends that he be good for the polis.

However, if there is a case of fundamental conflict (in which to help the poor somehow requires that one actually harm one's familial relationships), then one must first tend to the root of one's ren: the family. Mencius says:

Of duties, which is the greatest? The duty to parents is the greatest. What is the most important thing to watch over? One's own character. I have heard of a man who, not having allowed his character to be morally lost, is able to discharge his duties toward his parents; but I have not heard of one morally lost who is able to do so. There are many duties one should discharge [other than one's duties to parents], but the fulfillment of one's duty towards one's parents is the most basic. (4a19) ${ }^{26}$ [my italics]

So one's first duty is to family (and to parents in particular), but there are many duties to people outside of the family as well. If one has a good, ren character, one is committed to both kinds of duties (familial and non-familial duties). If one has a bad character, one fails at both kinds of duties. Later in 4a19, Mencius goes on to speak about extending the benevolence (ren). There Mencius says that the ren person will take joy in the fruits of doing these duties to parents and family, and once the joy in ren starts, one cannot stop the joy in ren as he extends it further to others.

Mencius goes on to say, "The content of ren is this: the duty to one's parents. The richest fruit of righteousness is this: the obeying one's elder brothers" (4a27). So the core of ren is in the commitment to one's relationships with parents and brothers. In the next passage, Mencius further develops this point and says:

Shun was able to look upon the fact that the empire, being greatly joyed, was turning to him.... When one does not please his parents, one cannot be a man; when one is not obedient to his parents, one cannot be a son. Shun did everything possible to serve his parents, and succeeded in the end in pleasing the Blind Man [Shun's father]. Once the Blind Man was pleased, the empire was transformed. Once the Blind Man was pleased, the pattern of relationships between father and son in the empire was set. This [pattern of relationships throughout the whole empire] is the supreme achievement of a dutiful son. (4a28) [my italics]

\footnotetext{
${ }^{26} \mathrm{Cf} .5 \mathrm{a} 4$, in which Mencius says, "Of all that a filial son can attain, there is nothing greater than honoring his parents."
} 
So the supreme duty to one's parents is to spread ren to the whole empire. Given the other passages in Mencius I have discussed, Mencius is not merely making the consequentialist point that Shun is setting an example for others to follow. Additionally, Shun's being good to his family is the foundation for Shun's being good to everyone (the latter necessarily following from the former), and Shun's being good to everyone is good for his family. Similarly, it is good for the teacher's parents that she is a good teacher. Doing good in the world, and having good relationships in the world, is a fundamental filial duty, according to Mencius. In other words, it is good for my parents that I do good generally throughout my life. One element of this is that, by having successful children, parents are successful. A parent's duty is to raise good children, and that is well done when the child indeed is successful (e.g., by being ren like a jun-zi). Similarly, a teacher is successful when she has successful students.

Ren is the good relationship one must have with all people in order to have good relationships with people sans phrase. Remember that ren is the foundation of the good relationship that the jun-zi has for people generally (7a45). Mencius' morally mature person is ren toward all people in the empire and all people within the Four Seas. Shun is ren toward his parents and the people, but he also is especially (and specially) attached to his parents. The ren relationships with people more generally is based upon the ren relationship with one's parents.

\subsection{SHUN'S COMMITMENT TO FAMILY AND EMPIRE}

Mencius' notion of extending ren from one's family implies that the moral foundations of ren are within one's commitment to one's own family. However, some might consider 7a35's discussion of Emperor Shun's supposed commitment to his father over the empire as an objection to my thesis. I will argue that (a) this case is not a case in which Shun must sacrifice the wellbeing of the empire for the sake of his filial duties, but (b) if it were such a case, then there are some extreme cases in which one must choose family over the good of the whole empire (but the general ethical demands for the jun-zi to help others remains strong).

Stephen Angle, for example, argues that there is a unity and a harmony among the virtues in the Confucian tradition, and that virtues such as ren (benevolence), xiao (filial piety or respect), and $y i$ (righteousness) are not in conflict on the Confucian tradition. Angle says, "[S]ome values may generally be more significant than others, but [the early Confucian] advocates the situation specific harmonization of all values in a manner that honors the importance of each distinct value" (Angle 2008, 36). Angle goes on to discuss Mencius' example of the sage Emperor Shun, who would leave the empire with his father on his back rather that hand his father over to the authorities for a crime. Mencius says,

Shun would have regarded abandoning the empire as though he were throwing away a 
worn-out shoe. He would secretly have taken his father on his back and fled to the edge of the Sea and lived there happily, never giving another thought to the empire" (7a35).

I believe that the Shun case is a case of the harmony of the virtues, in which Shun seeks the good of his father (thus respecting the virtue of xiao) while also leaving the empire in good condition (so ren still reins in the empire). I will now give my own interpretation of Mencius and give an account for more precisely how Mencius is harmonizing these competing values. I will employ a few passages to support my interpretation.

First, consider passage $2 \mathrm{a} 2$, where Mencius is discussing how the ruler is the primary example for all the ministers and people in the kingdom. Paraphrasing Confucius' Analects 12.19, Mencius says,

...[the higher official] sets the example [for those beneath him]. When someone above shows preference for anything, there is certain to be someone below who will outdo him [in seeking to satisfy that preference]. The virtue of the jun-zi is like wind; the virtue of the small man is like grass. Let the wind blow over the grass, and it is sure to bend. [The virtue of the kingdom] rests with the crown prince [after the death of the king].

Here Mencius is speaking to the crowned prince who inherits the empire upon the death of the ruler. Mencius, with Confucius, is arguing that a virtuous, true ruler makes the ministers, people, and also those who are to inherit the kingdom virtuous by example. Mencius believes that the virtue of the ruler spreads to those below him. So, Shun, who is supremely virtuous, can expect the ministers, the people, and those who are to inherit the empire to be virtuous after he is gone. After Shun is gone, the empire does not fall apart. Indeed, if the empire cannot thrive without Shun, then Shun has not been virtuous enough for the virtue to spread like wind blows grass. So if Shun actually had left the empire with his father on his back, the empire would have been left in good hands (if what Mencius says is true). The good emperor makes himself unnecessary.

However, why does Mencius say that Shun casts off the empire like a "worn-out shoe"? This might make it seem (to some interpreters) as if Shun did not value the wellbeing of those within the empire. However, there is an alternative explanation. Mencius indicates in some passages that the true ruler does not value being a ruler per se. Mencius says, "The jun-zi has three things in which he delights, and being a ruler over the empire is not one of them" (7a20). The three delights include virtuous things the jun-zi does with his family, with the people, and with students. The jun-zi who is a ruler (i.e., a true king) does not delight in being a ruler. What the true ruler like Shun delights in is doing good for others, and being a powerful ruler in itself is not one of them. One does not delight in being a ruler as one does not delight in worn-out shoes. Mencius suggests that one need not be a ruler to do good.

Mencius also says that in some sense the ruler is the least important person in the empire. Mencius says, "The people are of the highest importance; the alters to the gods of earth and grain come next; last comes the ruler. That is why he who gains the confidence of the multitudinous people will be emperor" (7b14). It is the good of the 
people that is important to the jun-zi and true ruler. The true ruler does not delight in being a ruler. These are some of the reasons why Shun can cast off the empire like an old shoe; the people had been provided for, and thus what remained of his being a ruler could be cast off. Moreover, a good ruler makes him or herself unnecessary for the wellbeing of the people. This making oneself unnecessary is part of what a good ruler needs to do for the sake of the wellbeing of the people.

However, Mencius' worn-shoe language could also indicate how much Shun values his father. This is consistent with what I argued earlier; the love of the family is the foundation of all virtue for Mencius, and the family does have priority over others. However, I also argued earlier that if Shun does not value his father, he does not value the empire (tian-xia), and vice versa. Mencius says that if one does not have ren for the family, one cannot extend ren to others, and if one does not extend one's ren to others outside the family, one cannot have ren for the family (1a7).

\section{ARISTOTLE ON PARTIALITY AND THE DEMANDS OF BENEVOLENCE}

As I argued earlier, the megalopsuchos is committed to the wellbeing of those in the polis. In Nicomachean Ethics I, Aristotle says that the highest end for a virtuous person is the good of the polis, which is the most godlike end with its large scope. In Politics I, Aristotle says that a good polis secures eudaimonia for those within the polis. The megalopsuchos deserves honor because he has achieved great things for the polis, and thus has secured substantial eudaimonia for those within the polis.

What I want to suggest here is that in being committed to the wellbeing of those within the polis, the magnanimous person extends his or her commitment to the wellbeing of the people. Only by being committed to the wellbeing of the people can the megalopsuchos have the proper "godlike scope of action" for the good of the polis. As I argued earlier, the virtue of megalopsuchia itself implies great benevolence for others, since that virtue requires one is willing to sacrifice one's life for the welling of others. This willingness to sacrifice indicates a strong commitment to the wellbeing of others.

However, is Aristotle's megalopsuchos merely motivated by a "godlike" scope of action, and not by benevolence? My answer is "no," since such godlike action requires benevolence. If one is not benevolent toward the polis, one is not godlike on Aristotle's view. If one is doing something merely for the sake of honor (or merely for "oneself to be great"), one is not magnanimous. The reason for this is that, for Aristotle, a virtuous person does a fine and noble (kalon) action for its own sake (1123a25). The megalopsuchos is worthy of honor because he acts for the wellbeing of the polis for its own sake. Similarly, in NE III.8, Aristotle says that the truly courageous person acts only for the sake of the noble and fine (kalon), which Aristotle also says is the wellbeing of the polis. Aristotle says that some people do courageous actions but are not fully courageous, since they do not act for the sake of the wellbeing of the polis. Rather, such non-courageous people do courageous actions for the sake of their respect for superior officers, or for the sake of avoiding shame or securing honor in the eyes of the citizens (1116a8-b18). To act courageous "for its 
own sake" is to act courageous for the sake of the good which is the telos of courage (and the telos of courage just is the wellbeing of the polis, which is constituted largely by the eudaimonia of the people of the polis).

So, Aristotle says that someone is not courageous if one acts merely for the sake of getting honor or avoiding shame; one is truly brave only if one acts for the wellbeing of the polis, which is noble and fine (kalon) (1116a8-b18). Similarly, the megalopsuchos acts not for the sake of honor, but for the sake of what is noble and fine (namely, the wellbeing of the polis). To be committed to the wellbeing of the polis means to be committed to the eudaimonia of those within the polis (and thus one must be benevolent towards others, so much so that one is willing to die for their wellbeing). So the megalopsuchos must be benevolent towards others, and care for others for their own sake, in order to have the virtue of megalopsuchia.

To put it in Mencian terms, the megalopsuchos must extend his concern and benevolence to all within the polis, much as the jun-zi must extend his benevolence (ren) to "all within the empire" and "all within the Four Seas". So the megalopsuchos' godlike motives (motives of great scope) are motives of benevolence, and are not contrary to it. The megalopsuchos is willing to die for the wellbeing of the polis, and he deserves great honor for this because he is benevolent toward the polis. ${ }^{27}$ The megalopsuchos is not seeking honor for its own sake (such honor seeking is not consistent with virtue).

However, what is the relation between the megalopsuchos' commitment to the polis and his commitment to his friends, his "near and dear"? Aristotle does not, as Mencius does, explicitly say that commitment to family is the foundation of virtue. However, for Aristotle a good upbringing within a family is central to developing virtue, and a commitment to that family may naturally come with such a virtuous upbringing (1095b3-9). ${ }^{28}$ So virtues are rooted in a virtuous family upbringing, in which commitments to family would naturally follow for the virtuous agent. Aristotle does spend much more time, however, discussing the relevance of friends than the relevance of family to the virtuous life. Aristotle says that a commitment to friends is a necessary condition for ethical goodness. How is the megalopsuchos' commitment to friends integrated with his commitment to the polis?

One way these commitments are integrated is that the various virtues are unified within the virtuous agent. Aristotle (famously) argues that there is a harmony and unity to the virtues (so much that if one has one virtue one has them all) (1144b1-17, 1144b31-1145a3). So, for Aristotle, one can both have a special ethical relationship with one's friends, and also be a megalopsuchos and do great things for the poor that are worthy of great honor. In other words, there is a unity and a harmony to the two virtues of philia (friendship) and megalopsuchia (magnanimity), just as there is a unity and harmony to the virtues of courage and friendship, or any other virtue and

${ }^{27}$ Cf. 1169b8-20, where Aristotle discusses how the true friend also will die for others, whose eudaimonia is a shared extension of his or her own.

${ }^{28}$ Cf. 1095b4-9. 
friendship. So the two virtues can be integrated much as the virtues of a good parent can be integrated with the virtues of a good teacher (which I discussed earlier).

Also, importantly Aristotle says that one's actions are more godlike when the action is shared with friends. For Aristotle, like Mencius, one needs the "near and dear," especially in friends, for support and help with the life of virtue. On Aristotle's view, one needs the virtue of philia to have (true) friends, and one needs true friends to have a godlike scope of action. What this means, if my previous arguments are correct, is that one cannot be greatly benevolent (and thus worthy of great honors) without friends. Let me explain this further in terms of the relationship between Aristotle's technical definitions of "friendship" and "things worthy of great honor."

Aristotle says that eudaimonia (as virtuous activity) is impossible without friends, and defines true friendship as shared virtuous activity. Aristotle says that "life" most fully just is activity, and a virtuous life is a life of virtuous activity (1100a12-13). Aristotle argues that humans, being social animals, cannot engage in fully excellent (i.e., virtuous) activity without the help of friends. For Aristotle, friends are not merely the consequentialist means to excellent activities; the shared activities of friends are literally a part of our activities, and as such are literally a part of our lives. Aristotle says that friends share the same being (1170b10), friends share a common life (1172a1-15), and that shared activities are more continuous activities (continuous activities being more godlike activities) (1170a5-12). ${ }^{29}$

Consider the activity of playing soccer. One might argue that, strictly speaking, soccer is an activity that requires competition among two groups of people according to certain rules. Thus, strictly speaking, one cannot play soccer alone; it is an activity that must be shared with one's teammates in competition with another team. The activity of "playing a soccer game" is shared among a group, is more continuous than the activity of a lone player, and thus (on Aristotle's view) one is sharing life (qua "life as activity") with the others in the group. Soccer is shared activity, and the shared activity (when done with virtue) is more continuous and excellent than the lone activity of a single player kicking a ball by herself.

Much as sharing activity is essential to soccer excellence, sharing activity is essential to a wide variety of human excellences according to Aristotle. Consider the discovery of DNA by Watson and Crick. From an Aristotelian point of view, it was not the lone activity of either Watson or Crick that constituted the activity of discovering DNA, but rather it was the shared activity of doing science together with a team that constituted the activity of the discovery. It is in the sharing of activity that scientists like Watson and Crick have been so successful. Aristotle thinks sharing activity (team activity) makes human activity more excellent. Thus, Aristotle thinks that true friendship (which just is "shared excellent human activity") is essential to eudiamonia (which just is "excellent human activity"). Given Aristotle's account, friendship is absolutely essential to the excellent activities that are worthy of great

\footnotetext{
${ }^{29}$ For a discussion of how shared activity is central to friendship, see Pangle 2003, and especially her chapter "Friendship and Politics within the Family". Also see Cooper 1977 for a discussion of the continuousness of the shared activity of friendship.
} 
honor (honors which are deserved by the megalopsuchos), since teamwork with other virtuous people makes the (shared) activity the most worthy of honors.

Let me explain this feature of the megalopsuchos with Rebecca DeYoung's account of Aristotle. Of Aristotle's megalopsuchos, DeYoung says:

Lastly, Aristotle's magnanimous person [megalopsuchos] is not the Lone Ranger when it comes to accomplishing great acts of virtue. Without a doubt, the magnanimous person seeks to be self-sufficient, but self-sufficiency in Aristotelian terms contrasts sharply with an American-style denial of our dependence on others. Human excellence depends on receiving a good upbringing in a city with good laws and cooperating with others to rule and defend the city. Even in the limit case of contemplation, Aristotle says it is more easily sustained in the company of friends who share one's good character. To be human is to be social by nature, and our acts of virtue find their place in this structure of human interdependence. (DeYoung 2004, 221)

DeYoung argues that for Aristotle the virtue of megalopsuchia is enhanced, rather than limited, by one's partial ethical commitments to friends through the virtue of philia and one's good upbringing in the family. On DeYoung's view (and mine), for Aristotle one cannot do great things without a commitment to friends presupposed in having the virtue of philia. For Aristotle, the ethically demanding virtues are rooted in one's partial relationships for both Aristotle and Mencius. It is through these close, special relationships that the benevolence is extended in scope, and becomes truly worthy of great honors.

\section{OPTIONS THAT MAXIMIZE UTILITY OR HARMONIZE WITH VIRTUE?}

The goal of the jun-zi and megalopsuchos is to excellently harmonize their commitment to the wellbeing of family and friends with their commitment to the wellbeing of the people in the "polis". I have argued that the polis (qua scope of concern) is the whole world today, both for Mencius' jun-zi (who cares for all within the empire and Four Seas) and Aristotle's megalopsuchos. There are many virtuous ways to harmonize these values, but most every way is very demanding for achieving the good within each domain (as is true for someone who is both a committed parent and a committed teacher).

How, then, does the commitment of the virtuous jun-zi or megalopsuchos compare to the demands of utilitarianism? On classical act utilitarianism (of which Peter Singer is a proponent), one is morally obligated to choose the "maximal option" (being the option that maximizes welfare as a consequence of choosing the option). On utilitarianism, an "option" is something an agent is able to do in the circumstances. At any one time, an agent had millions (or more) options, since an agent is able to do a huge variety of things, including moving, speaking, and generally acting in many, many slightly different ways. Many agents may be able to sing a song while stealing a friend's wallet, for example, at many times throughout the day. An agent may be able to hop on one leg while yelling Hamlet during a classroom discussion. 
The maximizing option among these many, many options might be ridiculous (since it is possible for just about anything to maximize utility in some possible world, given that it is possible that most anything could cause most anything). One example of a ridiculous maximizing option is those of licking stamps for Oxfam in a dark basement for years. This "Oxfam stamp licking for years" could maximize utility in some possible world. In choosing such ridiculous options, it is easily imaginable that one would not generally fulfill one's filial duties to family (or friends), and arguably one would have a life in which various important virtues are not fostered.

However, among the millions of options available to many agents in any one circumstance, there is probably an option near to maximization that is permissible for a virtuous agent like for a jun-zi or megalopsuchos that fulfills both one's filial duties and expresses the virtues. Among these is an option to have a good relationship both with one's family and the global poor. Mencius' "true king" can both be good to his family while also working very hard for the poor in the empire. What the true king cannot do is pursue one in a way that excludes the other when there are options that allow the king to pursue both over the course of his or her life. While there may be individual cases in which a virtuous agent must make a dramatic choice for one over the other, such cases are not common (as I have argued, Mencius' Shun case is not one).

However, there is only so much time in a day, and only so many actions that can be performed by even the best of us, and no agent can do and be everything to all people at every moment. The virtuous agent will do some actions that focus on family, and some actions that focus on the poor, and some actions that achieve both goods at the same time. Let us assume, for the sake of illustration, that there are one hundred actions a fully virtuous agent performs each day. There are millions (or billions, or more) permutations of those one hundred actions that a virtuous agent can perform that respect both the ren relationship with family and the ren relationship with the poor. Remember, on Mencius' view, one's relationship with family is both ren and "attached," while one's relationship with strangers is not "attached" but is ren, and the demands of ren are the demands of sensitivity, thoughtfulness, commitment, caring, and hard work.

A jun-zi and megalopsuchos will find many opportunities over the course of a whole life to do good for the poor, family, and friends. While the jun-zi and megalopsuchos will not maximize utility with every act, they will do noble things for the poor, family, and friends throughout his or her life. ${ }^{30} \mathrm{~A}$ jun-zi and megalopsuchos often will appear, at least in practice, to be like a very demanding "satisficing utilitarianism" (i.e., not maximizing good outcomes but getting "close enough" to it). A jun-zi and megalopsuchos need not always choose the maximal option, but will often in practice come as close to it as anyone does in real, daily life.

\footnotetext{
${ }^{30}$ Note that virtue does not always demand one get as close to maximization as possible. Many actions are permissible for virtuous, but the life of the virtuous is generally demanding, as the life of a virtuous teacher and parent is demanding.
} 


\section{SINGER'S MORAL DEMANDS IN "FAMINE, AFFLUENCE, \& MORALITY"}

Moreover, the moral demands on the jun-zi and megalopsuchos may be even more demanding that the demands for which Singer actually advocates in "Famine, Affluence, and Morality". Singer's demanding thesis is this: we are obligated to help the abject poor if it does not require sacrifice of (a) "anything morally significant" (the weak demanding thesis) or (b) "something of comparable moral importance" (the strong demanding thesis). Singer argues that either thesis does not depend on the truth of utilitarianism (Singer 1972, 237). Both versions of Singer's demanding thesis are not utilitarian, and thus Singer's thesis may not be as demanding as the utilitarian dictum to maximize utility.

Nevertheless, either thesis is very morally demanding (and impartialistic). On my arguments, the moral demands for a jun-zi and megalopsuchos are very demanding concerning the global, abject poor, and require much significant personal sacrifice (which may make it more demanding on balance than that of Singer's thesis). The megalopsuchos, remember, is willing to die for the wellbeing of the polis, and Singer's weak thesis hardly requires that kind of sacrifice (and that of the strong thesis as well, depending on how "comparable moral significance" is read). The jun-zi too is willing to die due to his commitment to what is ren (3b1, 5b7, 6a10, Cf. Analects 15.9). Thus, the demands on the jun-zi and megalopsuchos are clearly stronger than that of the weak thesis, since these are significant sacrifices. However, the jun-zi's great benevolence does not exist without his commitment to his family and virtue; the $j u n-z i$ will sacrifice much (including money, power, comfort, and his life) in pursuit of what is benevolent, but will not sacrifice his commitment to family and virtue.

Moreover, it is arguable that the demands on the jun-zi and megalopsuchos are as strong as that of the strong thesis, since they are committed to helping the poor (and even committed under some circumstances to dying for the poor) as long as it does not require sacrifice of something of "comparable moral significance" like the moral commitment to family and friends. As I have argued, if the jun-zi or megalopsuchos do not help the abject poor when they are able, there must be at least something else of comparative moral importance to do instead. This is true as well for a utilitarian, who must help the poor unless there is something else to do instead that has at least the same utility or more (the "same utility" being of "comparative moral importance" for a utilitarian). The jun-zi and megalopsuchos certainly would not sacrifice something as morally significant as their commitment to the wellbeing of family and friends. However, this sacrifice is not required of Singer's strong thesis in "Famine, Affluence, and Morality," since such sacrifice is arguably the kind of comparable moral sacrifice that Singer's thesis explicitly does not require.

Remember, Singer's strong thesis is not a utilitarian thesis, and so "comparable moral significance" cannot be interpreted merely in a utilitarian sense of comparable moral significance. According to Mencius and Aristotle, nothing is more morally significant than the moral commitments to family and friends, since the partial moral 
commitments to family and friends are the foundations of the moral life for Mencius and Aristotle. So, arguably, the ethical demands of Aristotle and Mencius are as demanding as Singer's strong thesis (given that commitment to family and friends is of "comparable moral significance"), and more demanding than Singer's weak thesis (given that sacrificing one's life is "morally significant").

\section{CONCLUSION}

The Aristotelian and the Mencian virtuous agent is not obligated to maximize utility, but is required to seek full virtue, in which the demands of virtue are harmonized. Such full virtue, as I have argued, comes with strong demands for the wellbeing of both the global poor and family and friends. Harmonizing those demands (as Shun does) is one of the things agents with full virtue do. Almost always, a person can find harmony among these demands. There are many options (in the utilitarian sense of options) that harmonize the values of family and the global poor, and are open options for a jun-zi or megalopsuchos.

Partialistic ethics is very demanding for both the jun-zi and the megalopsuchos. These ethical demands likely would lead both the jun-zi and megalopsuchos to help the global poor and hungry. Helping in a food emergency is just the kind of action that the jun-zi and megalopsuchos does. Such actions are of the great, benevolent kind that has significant impacts on the wellbeing of the community. Both the jun-zi and megalopsuchos are profoundly benevolent toward others, and thrive with a wide scope of action. This scope of action may well be global, as I have argued. Moreover, their virtues are available to us if we practice, and many of us have ample opportunity to practice benevolent actions.

\section{ACKNOWLEDGEMENTS}

I am grateful to three anonymous referees of Comparative Philosophy for their valuable comments on this article. I am also grateful for the helpful discussions I had with the good people of the Association of Chinese Philosophers in North America and the International Society for Comparative Studies of Chinese and Western Philosophy. I worked on this paper while in residence at the Institute for Advanced Study at the University of Minnesota, and I am also grateful for the Institute's support.

\section{REFERENCES}

Angle, Stephen (2008), “No Supreme Principle: Confucianism's Harmonization of Multiple Values", Dao, 7 (1): 35-40.

Angle, Stephen (2012), Contemporary Confucian Political Philosophy: Toward Progressive Confucianism (Oxford: Polity Press). 
Aristotle, The Complete Works of Aristotle, ed. Jonathan Barnes (1984), (Princeton, NJ: Princeton University Press).

Cooper, John (1977), "Friendship and the Good in Aristotle", Philosophical Review, 86 (3): 290-315.

Curzer, Howard (2012), "Benevolent Government Now", Comparative Philosophy, 3 (1): 74-85.

Curzer, Howard (1991), “Aristotle’s Much Maligned Megalopsychos”, Australasian Journal of Philosophy, 69 (2): 131-151.

DeYoung, Rebecca (2004), “Aquinas's Virtues of Acknowledged Dependence: A New Measure of Greatness," Faith and Philosophy, 21 (2): 214-227.

Foot, Philippa (1985), "Utilitarianism and the Virtues", Mind, 94: 196-209.

Hall, David and Roger Ames (1989), Thinking Through Confucius (Albany: SUNY Press).

Hardie, W.F.R. (1978), “"Magnanimity’ in Aristotle's Ethics”, Phronesis, 23 (1): 6379.

Jeske, Diane (1997), "Friendship, Virtue, and Impartiality", Philosophy and Phenomenological Research, 57: 51-72.

Kidder, Tracy (2003), Mountains Beyond Mountains: Healing the World: The Quest of Dr. Paul Farmer (New York: Random House).

Kim, Sungmoon (2011), "Confucian Constitutionalism: Mencius and Xunzi on Virtue, Ritual, and Royal Transmission”, The Review of Politics, 73: 371-399.

MacIntyre, Alasdair (1966), A Short History of Ethics (New York: Macmillan).

Mayhew, Robert (1997), Aristotle's Criticism of Plato's Republic (Lanham, Maryland: Rowman \& Littlefield).

Meikle, Scott (1995). Aristotle's Economic Thought (Oxford: Clarendon).

Mencius, Mencius, trans. D.C. Lau (2005), (New York: Penguin Classics).

Mingming, Wang (2012), "All Under Heaven (Tian-xia): Cosmological Perspectives and Political Ontologies in Pre-Modern China", Hau: Journal of Ethnographic Theory, 2 (1): 337-383.

Pangle, Lorraine Smith (2003), Aristotle and the Philosophy of Friendship (Cambridge: Cambridge University Press).

Qingping, Liu (2007), “Confucianism and Corruption: An Analysis of Shun's Two Actions Described by Mencius", Dao, 6 (1): 1-19.

Qiyong, Guo (2007), "Is Confucian Ethics a 'Consanguinism'," Dao 6(1): 21-37.

Sarkissian, Hagop (2010), "Recent Approaches to Confucian Filial Morality", Philosophy Compass 5 (9): 725-734.

Sherman, Nancy (1988), "Common Sense and Uncommon Virtue", Midwest Studies in Philosophy 13 (1): 97-114.

Singer, Peter (1972), "Famine, Affluence, and Morality", Philosophy and Public Affairs 229-243.

Stocker, Michael (1976), "The Schizophrenia of Modern Ethical Theories", The Journal of Philosophy 73 (14): 453-466.

Van Norden, Bryan (2007), Virtue Ethics and Consequentialism in Early Chinese Philosophy (NewYork: Cambridge University Press). 
Walsh, Sean (forthcoming), "The Varieties of Moral Luck in the Ethical and Political Philosophies of Confucius and Aristotle", in Stephen Angle and Michael Slote, eds., Virtue Ethics and Confucianism (New York: Routledge).

Williams, Bernard (1973), "A Critique of Utilitarianism", in J.J.C. Smart and Bernard Williams (eds.), Utilitarianism: For and Against (Cambridge: Cambridge University Press).

Wolf, Susan (1982), "Moral Saints,” Journal of Philosophy, 79 (8): 419-439. 